\title{
Adoption Dynamics of Improved Package of Practices on Sugarcane Cultivation by the Farmers of East Champaran District of Bihar
}

\author{
Satyam Kumar*, Anil Paswan and Chandan Kumar Panda \\ Department of Extension Education, Bihar Agricultural University, Sabour, \\ Bhagalpur, Bihar - 813210, India \\ *Corresponding author
}

\begin{tabular}{l} 
Ke y w or d s \\
Sugarcane, \\
Adoption, \\
Technology \\
\hline Article Info \\
\hline $\begin{array}{l}\text { Accepted: } \\
10 \text { May } 2019 \\
\text { Available Online: } \\
\text { 10 June } 2019\end{array}$ \\
\hline
\end{tabular}

Keywords

Sugarcane,

Adoption,

Technology

Article Info

Accepted:

Available Online:

10 June 2019

\begin{abstract}
A B S T R A C T
\end{abstract}
Sugarcane is the most significant cash crop. In all over the countries the India ranks first both in respect of area and total production among the sugarcane growing. Even if, there is remarkable opportunity for further progress in relation to increase the sugarcane production by way of adoption of modern technology in sugarcane cultivation. The adoption of improved technology of sugarcane by the farmers is not uniform due to several reasons. Hence, the present investigation was carried out during the year of 20016-2017 in four selected villages at Kotwa block in East Champaran district of Bihar state. 30 respondents were selected from each village by using simple random sampling procedure, thus the total 120 respondents were considered for the study. Information relating to various adoption levels was enlisted in pre-tested interview schedule. Oral interview was schedule was used to collect data from one hundred twenty (120) respondents who were randomly selected. The data were analyzed statistical percent and mean score analysis. The results of study revealed that majority of the respondents had medium level of adoption agronomical practices $(52.50 \%)$. It was also observed that adoption level in weed control medium level (47.50\%), and medium level in improved varieties $(35.883 \%)$. The result was indicated in adoption level was not improved in preparation of land (55.00\%), selection of land $(60.00 \%)$, fertilizers (35.00), insect pest management $(34.17 \%)$, disease management $(26.67 \%)$, and finally harvesting management $(55.00 \%)$.

\section{Introduction}

Agriculture is one of the most important sectors of the Indian Economy. In India Agriculture is the only revenue of living for almost two thirds of the workers. The agriculture region of India is contributing $16.1 \%$ of India's GDP and has occupied $43 \%$ of India's geographical area. Agriculture still contributes significantly to India's GDP despite decline of its share in India's GDP. There are large numbers of crops grown by farmers. These include different food crops, commercial crops, oil seeds etc., sugarcane is one of the important commercial cash crops grown in India. In Asia and Europe, Sugarcane is the most important source of sugar. Sugarcane is grown primarily in the tropical and sub-tropical zones of the southern hemisphere. Sugarcane is the raw material for 
the production of white sugar, jaggery (gur) and khandsari. It is also used for chewing and extraction of juice for beverage purpose. The major product of sugarcane is sucrose, which accumulates in the stalk internodes. Sucrose, extracted and purified in particular mill factories, is used as raw material in human food industries or is fermented to produce ethanol. Ethanol is produced on a large scale by the Brazilian sugarcane industry. Sugarcane is restrain to play a greater role in the Indian economy to come by offering a stable income to the farmers by way of cane price, by providing employment to rural masses, by realizing excise duty, purchase tax and foreign exchange earning to the years. The country of the world lying between the latitude 36.70 north and 31.00 south of the equator extending from tropical to subtropical zones which are growing sugarcane. In India sugarcane is cultivated from latitude $80 \mathrm{~N}$ to $330 \mathrm{~N}$, except cold hilly areas like Kashmir valley, Himachal Pradesh and Arunachal Pradesh. Sugarcane has a sucrose content of $10-18 \%$ and a fiber content of 10 $15 \%$ at harvest. The stems or stalks develop from buds, and are ready for harvesting 10-24 months later. It is essentially a plant of the warm tropics and grown best when frequent heavy rainfall is interspersed with bright sunshine. It is very sensitive to temperature below $15^{\circ} \mathrm{C}$ growth is very slow, and growth ceases when the temperature exceeds $35^{\circ} \mathrm{C}$. The optimum temperature range for sugarcane growth is $20-30^{\circ} \mathrm{C}$. There are many factors affecting sugarcane production such as choice of cane variety, climatic and soil conditions and availability of water. The current study focused on the training needs in adoption of sugarcane cultivation technology. The uptake of information technologies in the agriculture sector has lagged in comparison to other small and medium-sized businesses (Warren, 2004) and compared to non-agriculture business in general (Hagar and Haythornthwaite, 2005). There is needed to transformation of traditional subsistence farming into modern scientific farming through adoption improved technology. Starting the technologies from land preparation to post harvest of sugarcane like ridges and furrows, time of sowing, water management, method of sowing, varieties, seed rate, weed management, nutrient management, pest and disease management, harvesting and so on were developed to increase the production and productivity levels of sugarcane.

\section{Materials and Methods}

The present study was conducted in East Champaran district of Bihar state, where one block was selected for the study In this block there were 43 villages. A list of sugarcane villages was prepared with the help of Block Agriculture Officers of the block, out of which four villages were selected randomly were as followed, Kotwa, Dipau, Rajapur, and Barkurwa were randomly selected for the study on the basis of large area covered under sugarcane. Hence, total numbers of villages selected were four. The list of sugarcane producers cultivating sugarcane for last one year was obtained from Gram Sewak and using simple random sampling technique, thirty growers from each village were selected randomly. Thus, the sample size was worked out to 120 . A pre tested structured schedule was used to collect related data for year 201617. The respondents were interviewed at their homes and in some cases at ordinary place in the village. The intention of the study was also explained to the respondents. The theoretical range of scores was based on the calculation of individual adoption score of sugarcane practices. Possible score was worked out on the basis of degree of actual use of sugarcane production practices by an individual. On the basis of range of scores, thus, they classified into three categories based on mean \pm S.D. 


\section{Results and Discussion}

The results obtained from the current study as well as discussions have been summarized under following heads. All heads are based on the Package of practices of sugarcane cultivation in various tables.

\section{Adoption index of Agronomical practices}

The data in the table 1 revealed that distribution of sugarcane growers according to their adoption of agronomical practices. The data of the table show that most of sugarcane growers 52.50 per cent had medium adoption of agronomical practices of sugarcane cultivation technology followed by 18.34 per cent had low adoption of agronomical practices and 29.16 per cent had high adoption of agronomical practices.

\section{Adoption index of land preparation}

The data of table 2 indicated that out of total sugarcane growers 55.00 per cent were in the category of medium adoption of land preparation followed by 31.67 per cent had low in adoption of land preparation, whereas 13.33 per cent of the sugarcane grower comes under high adoption in land preparation.

\section{Adoption index of Varieties}

It was clearly indicated from the data in table 3 that out of total respondents 47.50 per cent had medium level of adoption of varieties of sugarcane. Whereas, 35.83 and 16.67 per cent of them had low and high level of adoption of sugarcane verities respectively.

\section{Adoption index of fertilizers management}

Table 4 revealed that a majority of the respondents (35.00 per cent) had medium adoption of fertilizers (42 members), followed by low adoption of fertilizers (59 members) i.e. 49.16 per cent, and high adoption of fertilizers (19 members) i.e. 15.84 per cent.

\section{Adoption index of irrigation management}

The result of Table 5 indicated that the majority of the respondents (52.50 per cent) had medium level of adoption of irrigation management, while followed by 35.84 per cent respondents had low level of adoption with rest of them of 11.64 per cent respondents had high level of adoption in irrigation management.

\section{Adoption index of weed management}

It was reported that from above table 6 show that most of sugarcane growers (47.50) had medium adoption of weed management of sugarcane cultivation technology followed by 29.16 per cent low and 23.34 per cent had high adoption improved technology.

\section{Adoption index of insect pest management}

In table 7 it was noted that most of sugarcane growers (58.33 per cent) had low adoption of insect pest management in sugarcane cultivation technology followed by 34.17 per cent medium and 7.50 per cent had high in insect pest management.

\section{Adoption index of disease management}

The data presented in Table 8 revealed that a higher percentage of respondents $(55.00$ per cent) belonged to low category of adoption of disease management, followed by medium category ( 26.67 per cent) and 18.33 per cent of the respondents had high category of adoption of disease management. 
Table.1 Distribution of sugarcane growers according to their adoption index of agronomical practices

\begin{tabular}{|c|c|c|c|}
\hline SI. No. & Categories & Frequency $(\boldsymbol{f})$ & Percentage(\%) \\
\hline $\mathbf{1}$ & Low (up to 25) & 35 & 29.16 \\
\hline $\mathbf{2}$ & Medium (26-63) & 63 & 52.50 \\
\hline $\mathbf{3}$ & High (>64) & 22 & 18.34 \\
\hline & Total & 120 & 100 \\
\hline
\end{tabular}

Mean $=43.83 \mathrm{SD}=18.33$

Table.2 Distribution of sugarcane growers according to their adoption index of land preparation

\begin{tabular}{|c|c|c|c|}
\hline Sl. No. & Categories & Frequency(f) & $\begin{array}{c}\text { Percentage } \\
(\mathbf{\%})\end{array}$ \\
\hline $\mathbf{1}$ & Low (up to 24) & 38 & 31.67 \\
\hline $\mathbf{2}$ & Medium (25-69) & 66 & 55.00 \\
\hline $\mathbf{3}$ & High (>70) & 16 & 13.33 \\
\hline & Total & 120 & 100 \\
\hline
\end{tabular}

Mean $=46.70 \mathrm{SD}=22.48$

Table.3 Distribution of sugarcane growers according to their adoption index of Varieties $\mathrm{n}=120$

\begin{tabular}{|c|c|c|c|}
\hline Sl. No. & Categories & Frequency $(f)$ & Percentage (\%) \\
\hline 1 & Low (up to 36 ) & 43 & 35.83 \\
\hline 2 & Medium (37-73) & 57 & 47.50 \\
\hline 3 & High $(>74)$ & 20 & 16.67 \\
\hline & Total & 120 & 100 \\
\hline
\end{tabular}

Mean $=54.99 \quad \mathrm{SD}=18.48$

Table.4 Distribution of sugarcane growers according to their adoption index of fertilizers management

\begin{tabular}{|c|c|c|c|}
\hline Sl. No. & Categories & Frequency $(\boldsymbol{f})$ & Percentage(\%) \\
\hline $\mathbf{1}$ & Low (up to 19) & 59 & 49.16 \\
\hline $\mathbf{2}$ & Medium (20-61) & 42 & 35.00 \\
\hline $\mathbf{3}$ & High $(>62)$ & 19 & 15.84 \\
\hline & Total & 120 & 100 \\
\hline
\end{tabular}

Table.5 Distribution of sugarcane growers according to their adoption index of irrigation management

\begin{tabular}{|c|c|c|c|}
\hline Sl. No. & Categories & Frequency $(\boldsymbol{f})$ & Percentage(\%) \\
\hline $\mathbf{1}$ & Low (up to 24) & 43 & 35.84 \\
\hline $\mathbf{2}$ & Medium (25-73) & 63 & 52.50 \\
\hline $\mathbf{3}$ & High (>74) & 14 & 11.64 \\
\hline & Total & 120 & 100 \\
\hline
\end{tabular}


Table.6 Distribution of sugarcane growers according to their adoption index of weed management $\mathrm{n}=120$

\begin{tabular}{|c|c|c|c|}
\hline SI. No. & Categories & Frequency $(\boldsymbol{f})$ & Percentage(\%) \\
\hline $\mathbf{1}$ & Low(up to 24) & 35 & 29.16 \\
\hline $\mathbf{2}$ & Medium(25-73) & 57 & 47.50 \\
\hline $\mathbf{3}$ & High(>74) & 28 & 23.34 \\
\hline & Total & $120 \quad$ SD $=15.98$ \\
\hline
\end{tabular}

Table.7 Distribution of sugarcane growers according to their adoption index of insect pest management $n=120$

\begin{tabular}{|c|c|c|c|}
\hline Sl. No. & Categories & Frequency $(f)$ & Percentage $(\%)$ \\
\hline 1 & Low(up to 29) & 70 & 58.33 \\
\hline 2 & Medium(30-63) & 41 & 34.17 \\
\hline 3 & $\operatorname{High}(>64)$ & 9 & 7.50 \\
\hline & Total & 120 & 100 \\
\hline
\end{tabular}

Table.8 Distribution of sugarcane growers according to their adoption index of disease management $\mathrm{n}=120$

\begin{tabular}{|c|c|c|c|}
\hline Sl. No. & Categories & Frequency $(f)$ & Percentage $(\%)$ \\
\hline 1 & Low(up to 30$)$ & 66 & 55.00 \\
\hline 2 & Medium(31-68) & 32 & 26.67 \\
\hline 3 & $\operatorname{High}(>69)$ & 22 & 18.33 \\
\hline & Total & 120 & 100 \\
\hline
\end{tabular}

Table.9 Distribution of sugarcane growers according to their adoption index of harvesting management $\mathrm{n}=120$

\begin{tabular}{|c|c|c|c|}
\hline Sl. No. & Categories & Frequency(f) & Percentage(\%) \\
\hline $\mathbf{1}$ & Low(up to 38) & 31 & 25.84 \\
\hline $\mathbf{2}$ & Medium(39-77) & 66 & 55.00 \\
\hline $\mathbf{3}$ & High(>78) & 23 & 19.16 \\
\hline & Total & 120 & 100 \\
\hline
\end{tabular}

Mean $=57.66 \mathrm{SD}=19.08$

\section{Adoption index of harvesting management}

Table 9 revealed that out of total sugarcane growers, 55.00 per cent had medium adoption level, 25.84 per cent growers had low adoption level, and 17.60 per cent growers had high adoption level of harvesting management. Adoption indicated that majority of the respondents had medium level of adoption agronomical practices (52.50\%), 
weed control $(47.50 \%)$, improved varieties $(35.883 \%)$, preparation of land $(55.00 \%)$, selection of land $(60.00 \%)$, fertilizers (35.00), insect pest management $(34.17 \%)$, disease management $(26.67 \%)$, and finally harvesting management (55.00).

The findings of Dutt and Mishra (2002) and Tiwari et al., (2007) support the present finding.

\section{Suggestions for further work}

This study was conducted within the time and resource limitations of a student researcher. But there is further scope for survey and action research in this field. Some of them are given below:

This study was conducted in only a single district. The study may be extended to the entire major sugarcane growing districts of the state to determine the findings and identity specific problems if there are any.

Research aimed at obtaining specific feed backs for development of suitable mechanized implements may be thought of, especially those which can reduce the drudgery of women.

\section{References}

Dutt, Triveni, Mishra Shri Ballabh (2002). Correlates of level of adoption of pulse production technology. Ind. Res. J. Ext. Edu., 2(1): 97-100

Hagar, C. and Haythornthwaite, C. (2005). Crisis, Farming \& Community. The Journal of Community Informatics, 1(3), 41-52.

Tiwari SG, Saxena KK, Khare NK, Khan AR (2007). Factors Associated with Adoption of Recommended Practices of Pea. Indian Research Journal of Extension Education 7(2\&3):60-61.

Warren, M. (2004). Farmers online: drivers and impediments in adoption of Internet in UK agricultural businesses. Journal of Small Business and Enterprise Development, 11(3), 371381

\section{How to cite this article:}

Satyam Kumar, Anil Paswan and Chandan Kumar Panda. 2019. Adoption Dynamics of Improved Package of Practices on Sugarcane Cultivation by the Farmers of East Champaran District of Bihar. Int.J.Curr.Microbiol.App.Sci. 8(06): 1086-1091.

doi: https://doi.org/10.20546/ijcmas.2019.806.134 